\title{
Correlation of Income Per-Capita, Secondary and Tertiary Education, and Environmental School Quantity to Achieve Clean Water Access in the Sustainable Development Goals
}

Submitted 06/08/20, $1^{\text {st }}$ revision 27/09/20, $2^{\text {nd }}$ revision 29/10/20, accepted 15/11/20

Ery Jayanti ${ }^{1}$, Yusri Hazmi ${ }^{2}$, Halik ${ }^{3}$, B.S Nazamuddin ${ }^{4}$, Teuku Zulkarnain ${ }^{5}$

\begin{abstract}
:
Purpose: Sustainable development is a new paradigm in the economic development literature as it integrates an approach comprising economic, environmental, and social factors. Its implementation aims to promote the citizens' quality of life, as highlighted in the Sustainable Development Goals agenda. One of them is an indicator to access clean water. This study empirically examines the extent to which the $n$ income per capita, secondary education, tertiary education (Education; ST), and quantity of environment school (ESQ) related to access to clean water of the Indonesian across 22 provinces in the country over the 2010-2018 data. Design/Methodology/Approach: The research model is a panel multiple regression approach; the study documented a significant relationship between income level, tertiary education level, a quantity of environment school (ESQ), and indicators of access to clean water.

Findings: These findings shed some light for the policymakers to design proper policies for achieving the citizens' quality of life by implementing the SDGs agenda so that the target of realizing "Zero Goals" was all Indonesian living by achieving sufficient access to clean water. Originality/Value: The study analyzes the implementation to promote the citizens' quality of life, as highlighted in the Sustainable Development Goals agenda. One of them is an indicator to access clean water.
\end{abstract}

Keywords: Millennium-Sustainable Development Goals, Clean Water Access, ESQ, FEM.

JEL Classification: D1, D12.

Article Type: Research paper.

${ }^{1}$ Universitas Jabal Ghafur, Indonesia, ery_jayanti@yahoo.com;

${ }^{2}$ Corresponding author, Politeknik Negeri Lhokseumawe, Indonesia, yusri@pnl.ac.id;

${ }^{3}$ Universitas Jabal Ghafur, Indonesia, halik@unigha.ac.id ;

${ }^{4}$ Universitas Syiah Kuala University, Indonesia, nazamuddin@unsyiah.ac.id;

${ }^{5}$ Politeknik Negeri Lhokseumawe, Indonesia, Indonesia, t.zulkarnain79@yahoo.com; 


\section{Introduction}

This study aimed to obtained empirical evidence through quantitative methods of the relationship between the access to clean water and per capita income, secondary education, tertiary education, and the environmental school quantity (ESQ) in Indonesia that have not yet reached the M-SDGs target. The Brundtland Commission Report of 1987, "Our Common Future for the Environment and Development," revealed the development paradigm's relationship focused on the economic aspect. Actions and sustainable development strategies are needed to ensure economic, social, and environmental balance and equality (WECD, 2016). The study conducted by Brinkman and Brinkman (2016) suggested that growth without development is just a compulsion to achieve numbers, and the growth is not based on the results as a measure of welfare improvement.

The development agenda in the Millennium-Sustainable Development Goals (MSDGs) is considered a development agenda that brings prosperity and has been appreciated by various countries globally, including Indonesia (Hoeuman et al., 2015). One of the M-SDGs' objectives is that the country must be able to reduce the number of people who do not have access to clean water. Until the MDG program ended in 2015, some countries were still unable to reduce the number; for example, in Europe, at least $11 \%$ of $17 \%$ of the region experienced water scarcity (Shan, Perren, and Zhang 2016). Dash et al. (2017), then in India, achieved clean water consumption for its population was only 47 percent. Cities in Iran are still experiencing water supply constraints due to the groundwater crisis (Madani, 2016). Fan et al. (2017) Around 400 out of 699 cities experiencing water scarcity from 2014 to 2016 in China. Likewise, in Afghanistan, only $48 \%$ of the population had access to safe drinking water (Haziq and Panesai, 2017).

Unequal access to clean water and sanitation also occurred in some sub-Saharan African countries (Berman, 2016). Indonesia is currently working to reduce the number of people who do not have access to clean water in the 2016-2030 SDGs period through the "Zero Goal" program (UNESCO, 2015). This program strives for all residents to have access to clean water (SDGs-2016).

However, from the results of monitoring that has been carried out, this program remains a formidable challenge for Indonesia and in some countries in the MDGs-SDGs (Wahyuningsih, 2016), and even there were still 119 million people (31 percent) who experienced water shortages (Rikerdas, 2016). At present, access to clean water in Indonesia is not by the targets in the MDGs-SDGs. Data from the Indonesian Central Statistics Agency (BPS) in 2018 show that the average consumption of clean water for the Indonesian population was 63.32 percent per province, and that achievement has not yet represented the entire population of Indonesia. Some provinces were still 
Correlation of Income Per-Capita, Secondary and Tertiary Education, and Environmental

School Quantity to Achieve Clean Water Access in the Sustainable Development Goals 890

under the average; for example, Papua was 42 percent, Bengkulu and Central Kalimantan were 40.02 percent. From the WHO and UNICEF Progress Drinking Water and Sanitation 2017 report, the level of access to clean water in Malaysia had reached 90 percent. Indonesia was on the second rank with the lowest water quality after India. Table 1 explains the factors that have led to the lack of access to clean water in several provinces in Indonesia according to the M-SDGs target. Table-1 illustrates the targets and achievements of the two M-SDGs agenda in Indonesia, namely the household access to clean water over the period 2010-2018. However, efforts to increase access to clean water for the Indonesian population have become an important agenda for the current administration. This can be seen from a series of government programs in developing human resources.

The effort to provide access to clean water in some regions of Indonesia from 20102015 was below the MDG target. Likewise, the target of SDGs for the period of 20162018 was still not as expected. Nevertheless, the government is optimistic that in 2030 the target can be achieved. Research related to access to clean water has been done before. Bryx and Bromberg (2010) stated that to realize the target of providing access to clean water, the government needs to make policies, especially concerning education and environmental knowledge improvement, set prices, and determine engineering and conservation methods to improve access to clean water. Rahmaningtias et al. (2013) examined the relationship between access to clean water and the average length of schooling. This research used a Random Effect Model.

Miftahuddin et al. (2013) examined the effect of per capita income and education level on access to clean water using the OLS model. Fan (2013) mentioned that there were attitude and behavior factors outside formal education for those who understand water source and use. However, it did not mention that this knowledge was obtained from Adiwiyata (Environmental) Schools. Davies et al. (2014) mentioned that water and water conservation education's availability are obligations of the government. Stevenson et al. (2016), in the UK, consumption of clean water will be more efficient, and the water supply is sufficient because the socialization of water conservation has been carried out. Zeneli (2016) found that education and per capita income influenced access to clean water.

In the same year, Zhang et al. (2016) conducted a study on domestic water demand in Tianjin. The consumer price index and income strongly influenced water demand. Prasetiyoputra and Sasimartoyo (2016) studied the effect of socioeconomic and demographic issues on access to clean water. Cronin et al. (2017) examined the correlation between the quality of household water consumption and factors of education level and income level using the OLS model. Fan et al. (2017) conducted a study on demographic, urbanization, and socioeconomic status factors on access to clean water.

Glabe and Hustsved (2017) investigated the sustainability of clean water consumption in Hispanic based on individual perspectives and behavior and knowledge of water 
use procedures. Nyanza et al. (2018) conducted a study on the effect of decent drinking water consumption on economic status and household characteristics. This study used a logistic regression model. Research on clean water access is an interesting issue, especially by using provincial data in Indonesia during the MDGs - SDGs period and panel data model analysis. Access to clean water is done through secondary education, tertiary education, and the number of Adiwiyata (Environmental) schools (ESQ) during the SDGs program. The research contributes to determining policies regarding access to clean water in Indonesia in the coming SDGs period and efforts to achieve "Zero Goals" in 2030.

\section{Literature Review}

\subsection{Access to Clean Water}

Clean water is one of the basic needs; everybody should have full access to drinking, cooking, bathing, and other hygienic life purposes (Ministry of Health, the Republic of Indonesia, 2014). Although Indonesia's government targets 100\% access to clean water by 2019, over the period 2016-2018, less than 50\% of the citizens had access to decent drinking water or protected piping water (National Socioeconomic Survey, 2017). Having full access to clean water becomes an obstacle when the living standard of the population is low. The knowledge about the importance of environment school quantity influences the level of clean water consumption. However, not many countries have applied environmental knowledge-based schools to formal schools (Liberman, 2018). Water use varies both indoor and outdoor.

Syme (2014) found that outdoor water consumption is influenced by income, lifestyle, water conservation education. Clean Water Statistics from BPS in 2016 mentions several indicators of the availability of clean water for the community, including quality, quantity, continuity, reliability of drinking water supply systems, and ease of both price and travel time. Clean water sources include piped water, quality, and healthy water. Clean water must consider construction away from the faces of disposal sites (MDGs, 2015).

According to Rand Water (2016), clean water is water quality that is safe for consumption, useful for all life on earth, free of chemicals or radioactive substances that are dangerous, and stable in corrosion or scaling. Some previous studies have concluded that high-income households tend to use more clean water than poor households. Chovves (2012) stated that households' ability to respond to clean water adequately is highly dependent on socioeconomic status. Dalhuisen et al. (2003) stated that water consumption is not elastic to changes in income for low-income countries. Many factors affect access to clean water, for example, socio-demographic (Duarte et al., 2013) and household characteristics (Syme et al., 2014). Nyanza (2018), Basu et al. (2017), and Ahmad et al. (2016) concluded that a factor related to access to clean 
Correlation of Income Per-Capita, Secondary and Tertiary Education, and Environmental

School Quantity to Achieve Clean Water Access in the Sustainable Development Goals 892

water is income. Haziq and Panesai (2017) observed the consumption of clean water in the city of Kandahar.

Out of 400 households, family income was the most influential factor in water in households. The lowest-income households depend on tap water supplied by the government. Low-income families were looking for free water sources to survive, and their water consumption was not of good quality. Similarly, Gunatilake (2015) stated that price, income, and education are important socioeconomic variables that influence safe drinking water preferences and demands. The results of Alihar's (2018) study stated that those with elementary education were indifferent to access to clean water. Per capita, water consumption per day from 130 cities in China increased significantly by $65 \%$ over $2000-2016$. The increase was strongly influenced by meteorological, socioeconomic, and income factors.

Using the Random Effect Model (REM), (Rachmaningtyas et al., 2013) found that education level and income had a positive and significant effect on access to clean water, specifically for piping services. In general, educated people will make large investments in the health sector, especially for low-involvement goods, such as drinking water (Vloerbergh et al., 2010). However, the research results by (Rachmaningtyas et al., 2013; Basu et al., 2017) contradict the results of research by (Cronin et al., 2017), who found that education level and income had no significant effect on clean water consumption. Wang et al. (2014) also concluded that formal education attitudes and behavior influenced access to clean water.

\subsection{Environmental School Quantity and Access to Clean Water}

Procedural knowledge or action effectiveness (knowledge effectiveness) has a stronger influence on behavior and ways of thinking on the environment than general education or declarative knowledge. Likewise, learning skills and active experience can produce greater behavior changes than passive knowledge acquisition (Dean, Fielding, and Newton, 2016). Environmental content that is integrated into character education is essential to be applied in formal schools. The concept of water literacy focusing on information processing on the importance of clean water sustainability will be obtained by those in environmental schools (Pane and Patriana, 2015; Karatas and Karatas, 2016). In some countries, schools have implemented environmental knowledge or included learning curricula in unitary environmental subjects, such as Brazil, Morocco, and Japan.

Rocha Kenya has 451 environmental schools that seek to promote environmental education and implement practical conservation initiatives in collaboration with schools, environmental groups, communities, and churches. An interesting development in this program is on environmental education by including it in the national curriculum. Schools in several countries have been named Adiwiyata schools, schools with environmental perspectives, and some of them have received awards from government 
agencies and environmentalists (IGES, 2015; Lieberman and Louv, 2018; Gachuru, 2015).

Likewise, Indonesia has 551 schools with environmental insight practically and academically participating in the Adiwiyata program $(\mathrm{KLH}, 2015)$. The Adiwiyata Program encourages creating knowledge and awareness of school members to preserve the environment, towards a healthy environment, and avoid negative environmental impacts (Kartika, 2018; Alsaad, 2011). According to the Ministry of Environment and the Ministry of National Education in 2017, schools aim to create good conditions in order to become a place of learning and to make the school members (teachers, students, and other workers) aware of their environment so that they can contribute and be responsible for saving the environment.

According to Puspita (2016), aspects that should be fulfilled by Adiwiyata schools include environmentally friendly and cultured school policies, environment-based curriculum, participatory-based activities, and having environmentally friendly supporting facilities and infrastructure. According to UNESCO (2008), the concept of environmental education as a scientific resource can be used in lifelong education to provide awareness of environmental issues and take a role in environmental conservation, environmental preservation management, and so on. Some studies have analyzed the correlation between environmental schools and access to clean water.

According to Dean et al. (2016), knowledge about clean water is related to behavior and attitudes the study results that used the random effects and fixed effects regression models mentioned the importance of knowledge related to clean water. These findings confirm the importance of community knowledge and identify potential subgroups that may require additional targeting to build knowledge. Furthermore, the research conducted on high school students in Brazil found that out of 2,649 students, only 356 students could complete water conservation through the scaling method after receiving previous training. This result shows that there was only a small correlation between environmental learning and water conservation practices (Carvaliho and Frizzo, 2016).

\section{Research Methods}

This research involved 198 observations of 22 research areas that have not yet achieved access to clean water according to the M-SDGs target and 9 years' time periods, namely 2010-2015 for the MDGs program and 2016-2018 for the SDGs program. Data of this study is obtained from the MDGs report, Ministry of Environment of Indonesia, the Indonesian Central Bureau of Statistics, and KLHK-RI 2010-2018.

$$
\mathrm{ACW}=\gamma_{0}+\gamma_{1} \mathrm{PINC}+\gamma_{2} \mathrm{EDS}+\gamma_{3} \mathrm{EDT}+\gamma_{4} \mathrm{ESQ}+\varepsilon_{\mathrm{i}}
$$



894

This study uses a balanced panel data, a combination of a cross-section of 22 provinces in Indonesia, and time-series data of 9 year-period, 2010-2015 (MDGs period) and 2016-2018 (SDGs period). One dependent variable of the Access to Clean Water (ACW) is regressed against four dependent variables of sustainable developments, namely the levels of Per Capita Income (PINC), secondary education (EDS), Tertiary Education (EDT), and Environment School Quantity (ESQ). The data panel modeling on the fixed-effect model (FEM) is the most efficient and suitable model (Berk, 2010; Cronin, 2017) to measure the effects of the sustainable agenda on the quality of life on the Indonesian population across 22 provinces nationwide. The estimated panel regression models are written as follows:

$$
A C W_{i t}=\gamma o+\gamma_{1} \operatorname{LnPINC}_{i t}+\gamma_{2} E D S_{i t}+\gamma_{3} E D T_{i t}+\gamma_{4} S E Q_{i t}+\varepsilon v_{i t} .
$$

The profile of access to clean water and sanitation standards in MDGs-SDGs in the Indonesian provinces is shown in Figure 1. The table shows the provinces with the achievement of access to clean water that is still below the MDGs-SDGs target.

Figure 1. Provinces Not Yet Achieved Access to Clean Water of M-SDGs Target

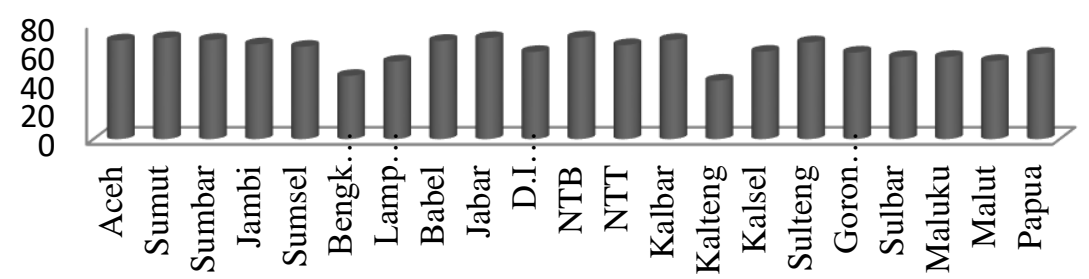

Source: MDGs Report 2015, BPS 2018.

Table 3. Descriptive Statistics of All Variables

\begin{tabular}{|c|c|c|c|}
\hline $\begin{array}{l}\text { Variable } \\
\text { Min }\end{array}$ & Obs & Mean & Deviation \\
\hline Access to Clean Water (ACW) & 198 & 56.217 & 15.117 \\
\hline $90.880 \quad 21.440$ & & & \\
\hline Income per capita (INC) & 198 & 1.121 .977 & 1.653 .112 \\
\hline $3.204 .420 \quad 9.983 .032$ & & & \\
\hline Secondary Education (EDS) & 198 & 25.416 & 5.699 \\
\hline 15.750 & 44.900 & & \\
\hline Tertiary Education (EDT) & 198 & 7.039 & 2.63 \\
\hline $15.540 \quad 1.220$ & & & \\
\hline Environment School Quantity (ESQ) & 198 & 4.699 & 4.157 \\
\hline $0.000 \quad 16.000$ & & & \\
\hline
\end{tabular}

Source: Own study.

The difference between the maximum and minimum figures for the variable access to clean water was huge in the nine years of research data, reaching 63 percent. The Jakarta province had the highest access to clean water in 2016 at 92.44 percent, and the lowest was Aceh province in 2010 at 29.02 percent and Maluku at 43.12 percent. 
The national average of access to clean water was only $62 \%$, still far from the target of $100 \%$. By 2018 the achievement of access to clean water by the population of Indonesia had not reached the target. The proportion of water usage was less than 20 liters per person per day in every household. Between 2013-2018 it had decreased from the national average of $20 \%$ to $5 \%$ (SUSENAS, 2018).

\section{Brief Overview of the Access to Clean Water of the MDGs-SDGs}

Before discussing the main finding, this section describes access to clean water for the population. The income per capita, secondary and tertiary education (STE), and several environmental schools (ESQ) As illustrated in Table 4, on the average, the levels of national clean water access (ACW), income per capita (PINC), secondary education (EDS), tertiary education (EDT), and several environmental schools (ESQ) across 22 provinces in Indonesia for the period 2010-2018 was 25\%, 23\%, IDR702.69 thousand, $25.77 \%, 7.26 \%, 33.28 \%, 35.06 \%$, and $20.16 \%$, respectively. Bali province had the highest value of the ACW by $74.23 \%$, while Papua's province is recorded as the lowest level of the ACW by $44.68 \%$. In terms of income per capita, Jakarta's province recorded the highest level of income (IDR1.527.90 thousand), while the province of East Nusa Tenggara recorded the lowest income per capita (USD 437.32 thousand).

Table 4. Mean Values of the Access Clean Water and Income Per Capita, STE, ESQ in Indonesia Provinces

\begin{tabular}{llllcc}
\hline Province & ACW $(\%)$ & INC(IDR000) & EDS (\%) & EDT(\%) & ESQ(\%) \\
Aceh & 51.52 & 717.42 & 29.69 & 7.86 & 7 \\
North Sumatera & 60.73 & 636.88 & 31.67 & 6.90 & 15 \\
West Sumatera & 58.64 & 734.27 & 26.74 & 8.08 & 4 \\
Jambi & 57.42 & 668.46 & 34.71 & 7.58 & 0 \\
South Sumatera & 60.21 & 623.39 & 23.54 & 5.52 & 1 \\
Bengkulu & 35.93 & 644.47 & 24.50 & 6.62 & 3 \\
Lampung & 52.50 & 573.74 & 21.95 & 4.55 & 9 \\
Bangka Belitung & 54.72 & 876.49 & 23.77 & 6.36 & 3 \\
East Java & 61.60 & $1,081.21$ & 31.12 & 5.85 & 12 \\
West Java & 57.34 & 720.56 & 21.90 & 5.87 & 113 \\
Banten & 51.72 & 816.76 & 23.06 & 6.16 & 6 \\
WestNusaTenggara & 60.09 & 545.45 & 20.19 & 5.98 & 9 \\
East Nusa Tenggara & 56.74 & 437.32 & 18.41 & 6.54 & 12 \\
West Kalimantan & 61.72 & 635.53 & 19.53 & 4.27 & 2 \\
Central Kalimantan & 51.13 & 682.25 & 22.11 & 5.58 & 1 \\
South Kalimantan & 56.88 & 788.41 & 21.48 & 5.91 & 17 \\
Central Sulawesi & 54.41 & 624.29 & 21.79 & 6.86 & 3 \\
Gorontalo & 58.38 & 577.93 & 18.99 & 5.71 & 3 \\
West Sulawesi & 47.14 & 477.29 & 21.60 & 8.51 & 4 \\
Maluku & 60.52 & 536.43 & 32.94 & 8.46 & 1 \\
North Maluku & 57.69 & 551.25 & 26.46 & 6.85 & 1 \\
\hline
\end{tabular}


Correlation of Income Per-Capita, Secondary and Tertiary Education, and Environmental

School Quantity to Achieve Clean Water Access in the Sustainable Development Goals 896

\begin{tabular}{lllllc}
\hline Papua & 44.58 & 672.70 & 25.88 & 8.73 & 3 \\
Mean & $\mathbf{5 8 . 4 1}$ & $\mathbf{7 0 2 . 6 9}$ & $\mathbf{2 5 . 7 7}$ & $\mathbf{7 . 2 6}$ & $\mathbf{1 3 . 2 8}$ \\
\hline
\end{tabular}

Source: Own study.

Table 4 shows the decline in access to clean water in some provinces in Indonesia has not been achieved as targeted in sustainable development goals. On average, the achievement of access to clean water was $55.13 \%$, respectively, which are still far from the "zero Goals and 100\% target. Table 2 also shows a different level of income, education, and school environment quantity across 22 provinces nationwide. Does different achievement of the clean water access relate to the different levels of income, education, and environment school quantity (ESQ) the provinces in Indonesia? In the next section, this question is answered. Next, in the view of education level, the largest population of the province of Jakarta, Indonesia's capital city was graduated the secondary education $(38.41 \%)$ and tertiary education $(15.59 \%)$ levels.

In comparison, the smallest population with the secondary and tertiary education levels were found in the provinces of East Nusa Tenggara (18.41\%) and West Kaliman$\tan (4.27 \%)$, respectively. Nationally, the number of environmental schools in Indonesia is minimal. On average, there are only 23 units for each region. Even provinces that do not have that kind of school, such as South Sulawesi, North Sulawesi, Central Kalimantan. Provinces with many environmental schools are West Java (113 units) and South Kalimantan (17 units).

\section{Results and Discussion}

\subsection{Main Findings and Discussion}

In this section, the GLS model's findings on the influences of income, education' ST, and ESQ on access to clean water are reported. However, before this, the first step of the study is to identify the most suitable GLS model to estimate the panel data. In selecting the most suitable three-panel models among the Common Effect Model (CEM), random effect model (REM), and Fixed Effect Model (FEM), both the Redundant, Housman tests. As reported in Table 4, based on these tests, both the Redundant and Housman tests are conducted, the fixed-effect model (FEM) is found to be a better model than those of CEM and REM to analyze our data, as indicated by the pvalue of the tests which were smaller than its $5 \%$ level of significance. In other words, the fixed-effect model (FEM) model is found to be the most appropriate model to be adopted in the study to estimate the influences of Income per capita, Education' ST, ESQ on access to clean water. The best model test results used are those shown in table 5 .

Table 5. Test Selection of the Best Model for Estimating Clean Water Access Indicators

\begin{tabular}{lllllll}
\hline Variable & Common & & FEM & \multicolumn{3}{l}{ REM } \\
\hline C & 40.47237 & $(10.5061)^{*}$ & 32.90102 & $(4,842)^{*}$ & 8.127033 & $(8.1270)^{*}$ \\
INC & 0.000055 & $(3.3716)^{*}$ & 0.000001 & $(2,712)^{*}$ & 0.0000005 & $(3.7507)^{*}$ \\
EDS & -0.0541 & $(-0.3573)$ & -002417 & $(-1.0139)$ & 0.1604 & $(-0.1450)$ \\
\hline
\end{tabular}




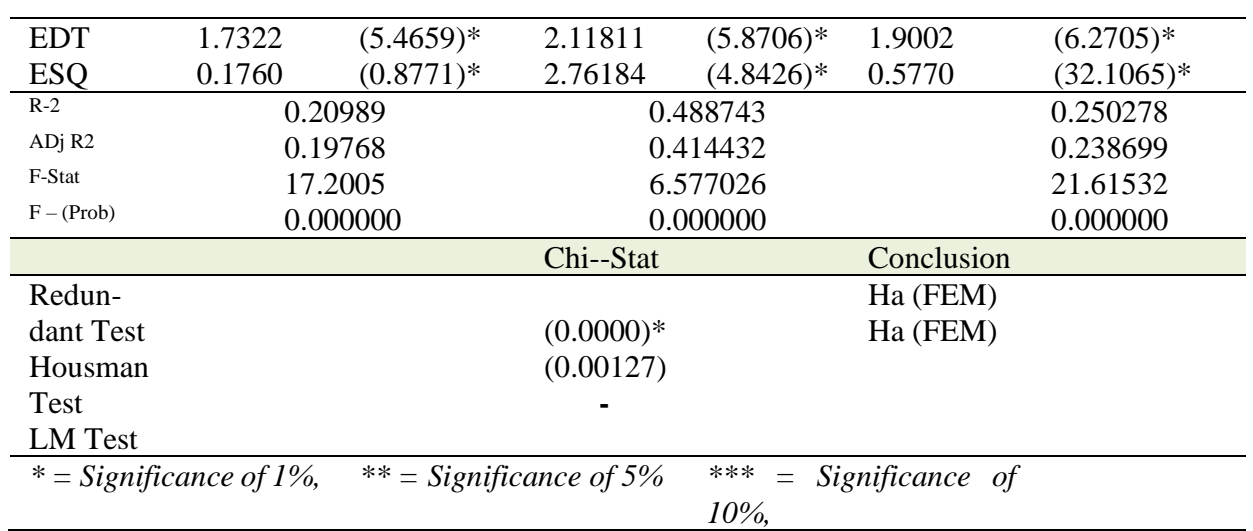

Source: Own study.

\subsection{Clean Water Access and Its Influencing Factors}

The findings of the effects of income, education 'ST, environment school quantity (ESQ) the sustainable development goal from the Access Clean Water perspective are reported in Table 4. As the study identified the FEM is the best model to be adopted in this study, thus the discussion only focused on the findings of FEM. As observed from Table 5, the study documented a positive relationship between Income per capita Education 'ST, ESQ factors on the access to clean water at least at the 5\% significance level.

Table 5. Effect of on Access Clean Water and Sanitation in Indonesia

\begin{tabular}{|c|c|c|c|c|c|c|c|c|c|}
\hline \multirow[t]{2}{*}{ Model } & \multirow{2}{*}{$\begin{array}{l}\text { Depend- } \\
\text { ent Varia- } \\
\text { ble }\end{array}$} & \multirow{2}{*}{$\begin{array}{l}\text { Inde- } \\
\text { pendent } \\
\text { Variable }\end{array}$} & \multirow[t]{2}{*}{ Coefficient } & \multirow[t]{2}{*}{$\mathrm{R}^{2}$} & \multirow[t]{2}{*}{ Adj-R ${ }^{2}$} & \multirow[t]{2}{*}{$\begin{array}{l}\text { F- } \\
\text { Value }\end{array}$} & \multicolumn{3}{|c|}{ Model Selection } \\
\hline & & & & & & & $\begin{array}{l}\text { Chow } \\
\text { Test }\end{array}$ & H-Test & $\begin{array}{l}\text { LM } \\
- \\
\text { Tes } \\
t\end{array}$ \\
\hline $\begin{array}{l}\text { FEM } \\
\text { (1) }\end{array}$ & $\begin{array}{l}\text { Access } \\
\text { clean } \\
\text { water } \\
(\mathrm{ACW})\end{array}$ & $\begin{array}{l}\text { Constant } \\
\text { INC } \\
\text { EDS } \\
\text { EDT } \\
\text { ESQ }\end{array}$ & $\begin{array}{l}32.90102^{* * *} \\
(4.824)^{*} \\
0.000001 \\
(2.712)^{*} \\
-02417 \\
(-1.013) \\
1.9488 \\
(5.870)^{*} \\
2.7618 \\
(4.660)^{*}\end{array}$ & 0.4887 & 0.4144 & $\begin{array}{l}6.5770 \\
{[0.000]} \\
* * * *\end{array}$ & $\begin{array}{l}31.227 \\
(0.000) \\
* * *\end{array}$ & $\begin{array}{l}12.733 \\
(0.0127\end{array}$ & - \\
\hline
\end{tabular}

Note: Figures in (.) indicate $t$-statistics and probability value, while the ${ }^{*}$ indicate significance at the 5\%, levels, respectively.

Source: Own study.

Overall, these factors explained the variations in access to clean water by $41.44 \%$, as indicated by the adjusted R-square value of 0.4144 . This finding indicates that the achievement of the clean water access target is found to be most affected the Income 

898

per capita, tertiary education, and ESQ factors; this finding is in line with the study by (Carvaliho and Frizzo, 2016; Chovves, 2012) who found that those variables were positively related to the Access Clean Water (ACW). This further confirms that if the government intends to achieve sustainable development of access to clean water, the focus should be on improving income, promoting tertiary education, and being more sensitive to affective, cognitive, and psychomotor attitudes. The government needs to increase the number of Adiwiyata schools that contribute directly to environmental development in their respective regions. Compared to all quality of life factors, income was found to be a factor affecting achieving the MDGs-SDGs' target of increasing access to clean water.

Particularly, if the per capita income is increased by $1 \%$, access to clean water could be increased by $0.5 \%$. However, the tertiary education level has contributed more to the increasing access to clean water by $1.94 \%$ than the secondary level of education not contributed to the increased clean access water. This further indicated that a higher level of education is necessarily needed to access clean water increase as with a higher level of education status would get to improve behavior. Rahmaningtias et al. (2013) said that those with higher education levels would be oriented towards being more concerned about health by consuming clean water.

Environmental school factors have a positive effect on access to clean water by $2.22 \%$. This is in line with the findings of Karatas and Karatas, (2015) finally, in the view of tertiary education, ESQ and per capita income affect access to clean water. This suggests that higher income influences the level of access to clean water independently even though some of those with less income are still given subsidized water. Gunatilake (2015) stated that those with better income per capita tend to access higher clean water. This finding is in line with the results of Basu et al. (2017), Haziq and Panesai (2017), and Nyanza (2018), who found that socioeconomic variables are essential variables that affect access to safe drinking water.

Overall, our findings are supported by previous studies such as (Chooves, 2012; Wang et al., 2016), who recorded that an increased income has significantly increased access to clean water. The significance of education levels tertiary in increased the access clean water is in line with the studies by (Thapa, 2013; Nwokolo 2015; Saad et al., 2011). Basu et al. (2017), according to them, the education level, especially the tertiary education level, has significantly contributed to clean water access.

However, our findings on the insignificant influence of secondary education on the increased access to clean water. Alihar (2018) stated that the population with elementary education was indifferent to access to clean water. Cronin et al. (2017) stated that education does not affect access to clean water and does not guarantee that clean water consumption is not contaminated. Kang et al. (2017) and Fan et al. (2014) stated that water access and water use procedures are highly dependent on attitudes and behavior, not on formal education. Therefore, in their study, Dean, Filding, and Newton (2016) found that the relationship between many environmental schools (ESQ) or educational 
institutions that apply environmental knowledge. They concluded that environmental knowledge needs to be applied early. Stevenson et al. (2016) stated that the consumption of clean water would be more efficient, and water supply is fulfilled because of water conservation promotion.

Our findings further suggest the importance of the government to prioritize the quality of life increase agenda on promoting the socioeconomic status of the citizens as it positively contributes towards the increase in the basic means of population needs in Indonesia, and consequently would realize the aspiration of SDGs' target in the country. The education institutions should pay more attention to the quality of higher education oriented to learning-by-doing so that the graduates that would be produced not only academically intelligent but also psychometrically intelligent. Creating more open employment through financial support would enhance the per capita income of the population and, in turn, realize the country's aspiration to achieve the SDGs' target by 2030 .

\section{Conclusions and Recommendation}

As for the access to clean water, the study documented the highest contribution of the tertiary level of education to the increase in clean water access, followed by the increase in population per capita income. However, the secondary level of education was found to affect clean water access adversely. These findings further indicate the population's significance to have a higher education level, particularly knowledge of importance to living healthily by consuming hygienic water.

Thus, to achieve the sustainable development targets of fully uplifting the population from poverty and hunger and provides full access to clean water, the government should design policies focusing on enhancing the quality of life of the citizens. Granting more scholarships for the poor-smart students and creating more jobs by giving financial support to the SMEs nationwide would enhance the population's per capita income, education level, and employment opportunities. This would, in turn, realize the country's aspiration to achieve the sustainable development target of "zero goals" by 2030. To accelerate the sustainable development target of full clean water access, the government might provide subsidies or granting free access for the poor to clean water nationwide.

Further studies on achieving sustainable development in Indonesia could provide better and comprehensive empirical findings by considering more variables in the model of estimation. These factors could include the water infrastructures, the level of rainfall, the level of population awareness of the healthy life, forest damage rates, quality, and quantity of raw water supply, etc. Other political, socioeconomic, technological, legal, and environmental factors might also be considered. Additionally, comparing different countries across the regions into the analysis would 

900

also enrich the existing empirical shreds of evidence on influences of quality of life factor on realizing the sustainable development target. Finally, comparing the private and public organizations would also enrich the current empirical findings on the investigated topic. The situation of Indonesia, which is prone to environmental damage, will impact the availability of clean water. The researchers state that access to clean water is an urgency in the context of our education, especially environmental education.

\section{References:}

Ahmad, S., Mirza, M.U., Ali, S.H., Lotia, H. 2016. Analysing Household Water Demand in Urban Areas. Pakistan: International Growth Centre (ICG)-LSE.

Alsaad, I. 2011. Panduan Adiwiyata Sekolah Peduli dan Berbudaya Lingkungan. Jakarta: Deputi Bidang Komunikasi Lingkungan dan Pemberdayaan Msyarakat. SLHI-RI. Jakarta.

Badan Pusat Statistik. 2016. Statistik Air Bersih-Indonesia, Mewujudkan Aksesibilitas Air Minum dan Sanitasi yang Aman dan Berkelanjutan. Hasil Survei Kualitas Air Daerah. PPN/BAPPENAS, Kementrian Kesehatan.

Badan Pusat Statistik. 2018. Kajian Indicator Lintas Sector. Potret Awal Tujuan Pembangunan Berkelanjutan Sustainability Development Goals di Indonesia, 919907. ISBN: 1850-0963.

Basu, S.H., Shizuka Hashimoto. 2017. Determinant of water consumption: A Cross-sectional Household study in Drought Prone Rural India. International Journal of Disaster Risk Reduction, 24, 373-383. DOI: 10.1016/j.ijdrr.2017.06.026.

Berk, R. 2010. An Introduction to Statistical Learning from a Regression Perspective. In: Handbook of Quantitative Criminology, 725-740, New York, NY: Springer.

Brinkman, R. 2016. Economic Growth Versus Economic Development: Toward a Conceptual Clarification. Journal of Economic Issues, 29(4), 1171-1188. DOI: 10.1080/00213624.1995.11505746.

Berman, J. 2014. Akses Terhadap Air Bersih dan Sanitasi di Afrika Tidak Merata. VOA Afrika. Retrieved from: https://www.voaindonesia.com/a/1899785.

Becker, S. 2015. Capacity Analysis for Evaluating Water and Sanitation Infrastructural Choice for Developing Commodities, 1(6), 335-343.

Berk, R. 2010. An Introduction to Statistical Learning from a Regression Perspective. Handbook of Quantitative Criminology, 725-740, New York, NY: Springer.

Brundtland, G.H. 1987. Report of The World Commission on Environment and Development. The United Nation.

Bryx, D., Bromberg, G. 2009. Best Practices in Domestic Water Demand Management. Tel Aviv, Israel. Retrieved from: consensus.ie/wp/wp-content/uploads/2013/11/RUTHDOYLE-THESIS, 1.

Carvaliho. I.C., De Moura., F.T., Ernst, C. 2016. Environmental Education in Brazil. Encyclopedia of Educational Philosophy and Theory. Doi: 10.1007/978-981-287-532-7, 316-1

Cronin, A.A., Odagiri, M., Arsyad, B., Nuryetti, M.T., Amannullah, G., Santoso, H., Nasution, N. 2017. Piloting Water Quality Testing Coupled With An National Socioenonomic Survei In Yogyakarta Province,Indonesia, Towards Tracking of Sustainable Development Goal 6. International Journal of Hygiene and Environmental Health, 1-11. DOI: 10.1016/j.ijheh.2017.07.001. 
Dalhusein, J.M., Florax, R.J.G.M., De Groot, H.L.F., Nijkamp, P. 2003. Price and Income Elasticity of Urban Residential Water Demand: A Meta-Analysis. Land Economics, 79, 292-308.

Dash, D.K. 2013. 22 of India's 32 Big Cities Face Water Crisis. The Times of India, New Delhi, India. Retrieved from: times of India. India times.com/india/22-of-Indias32big-cities-face-water-isis/articleshow/22426076.cms.

Davies, K., Doolan, C., Van Den Honert, R., Shi, R. 2014. Water Saving Impacts of Smart Meter Technology: an empirical 5 year, Whole-of-Community Study in Sydney, Australia', Water Resource, 50 (9), 7348-7358.

Duarte, R., Pinilla, V., Serrano, A. 2013. Is There an Environmental Kuznets Curve for Water Use. A panel smooth transition regression approach. Economic Modelling, 31, 518-527.

Hoelman, M.B., Parhusip, B.T., Eko, S., Bahagijo, S., Santono, H. 2015. Panduan SDGs untuk Pemerintah Daerah dan Pemangku Kepentingan Daerah. Jakarta: IMFID.

Fan, L., Liu, G., Wang, F., Geissen, V., Ritsema. C.J. 2013. Factors Affecting Domestic Water Consumption in Rural Households upon Access to Improved Water Supply: Insights from the Wei River Basin, China. PLoS one, 8(8), e71977. doi:10.1371/journal.pone.0071977.

Fan, L., Gai, L., Tong, Y., Li, R. 2017. Urban Water Consumption and Its Influencing Factors in China: evident from 286 Cities. Journal of Cleaner Production. Elsevier Science Direct, 166, 124-133.

Fan, L., Liu, G., Wang, F., Geissen, V., Ritsema, C.J. 2013. Factors Affecting Domestic Water Consumption in Rural Households Upon Access to Improved Water Supply: Insights from the Wei River Basin, China. PLOS One, 8(8), 1-9. https://doi.org/10.1371/journal.pone.0071977.

Goetz, S.J., Fleming, D.A., Rupasingha, A. 2012. The Economic Impacts of SelfEmployment. Journal of Agricultural and Applied Economics, 44(3), 315-321.

Gunatilake, M. 2015. Drought and Household Food Security in Rural Sri Lanka: A Case Study. Journal Landslides, 7(2), 78-86.

Haziq, P. 2017. An Empirical Analysis of Domestic Water Resources Consumption, and Located Factor in Kandahar City, Afghanistan. Journal Resources and Development, 77(2), 49-61.

Hobgen, S., Miyer, F., Wasson, R. 2016. New Research on Water Resources. Retrieved from: https://media.neliti.com/media/journals/logo-358-prakarsa.png.

IGES. 2015. Workshop on Sustainable Development Goals: National Implementation Challenges. Retrieved from: https://www.asef.org/projects/themes/sustainable-development/3676.

Kang, J., Grable, K., Hustvedt, G. 2017. Sustainable Water Consumption: The Perspective of Hispanic Consumers. Journal of Environmental Psychology, 11.1(17).

Karatas, A., Karatas, E. 2016. Environment Education as a Solution Too for the Prevention of Water Pollution. Journal of Survey Fisheries Sciences, 3(1), 61-72.

Kartika, L.A. 2018. The Influence of Adiwiyata School Program Against the Student's Care Behavior. Tesis, Fakultas Sosiologi Politik Universitas Lampung.

Kemenkes, K. 2014. POGJA AMPL Kelompok Kerja Air Minum dan Penyehatan Lingkungan. Retrieved from: http://www.ampl.or.id/digilib/read/24-no-492menkes-per-iv-2010/50471. 
Correlation of Income Per-Capita, Secondary and Tertiary Education, and Environmental

School Quantity to Achieve Clean Water Access in the Sustainable Development Goals 902

Kementrian Lingkungan Hidup dan Kehutanan. 2015. Status Lingkungan Hidup Indonesia 2015. Jakarta-Indonesia. Catalog: 3305001.

Kementrian Lingkungan Hidup dan Kehutanan. 2016. Status Lingkungan Hidup Indonesia 2016, Jakarta-Indonesia. Catalog: 3305001.

Kementrian Lingkungan Hidup dan Kehutanan. 2017. Status Lingkungan Hidup Indonesia SLHI Indonesia. 2017. Jakarta-Indonesia. Catalog: 3305002.

Kementrian Lingkungan Hidup dan Kehutanan. 2018. Status Lingkungan Hidup Indonesia. Jakarta - Indonesia. Catalog: 3305003.

Lieberman, G.A. 2018. Education and the Environment Creating Standard-Based Program in the Schools and District the EIC Model ${ }^{\mathrm{TM}}$ Environment as an Integrating Context Improving Student Learning. Edison Revise by Harvard Education Press.

Lotia, H. Mirza, M.U., Ali, S.H., Ahmad, S. 2016. Analysing Household Water Demand in Urban Areas. Pakistan: International Growth Centre (ICG)-LSE.

Madani, K. 2014. Water Management in Iran: What is Causing the Looming Crisis? Journal of Environmental Studies and Science, 4(4), 315-328.

Marinoski, A.K., Viera, A.S., Silva, A.S., Ghisi, E. 2014. Water end Used in Low Income Houses in Southern Brazil, 1985-1999.

Miftahuddin. 2013. Analisa Karakteristik Rumah Tangga Miskin dengan Metode Regresi Logistik. Jurnal Matematika, Statistik da Komputasi JMSK, 7(2), 79-91. http:// jurnal Unhas ac.id.index php jmsk. ISSN 1858-1382.

Moerek, O.I. 2017. Challenges for Water Supply and Sanitation in Developing Countries: Case Studies from Zimbabwe. Journal Managing Urban Water is Transmission. 91119. Springer Link.

Nyanza, E.C., Jahanpour, O., Hatfield, J.M., Van der Meer, F., Allen-Scott. L., Orsel, K., Bastien, S. 2018. Access and Utilization of Water and Sanitation Facilities and Their Determinants Among Pastoralists in The Rural Areas of Northern Tanzania. Tanzania Journal of Health Research, 20(1). Retrieved from: http://www.academicjournal.org/JEAPS 10.058.

Pane, M.M., Patriana, R. 2015. The Significance of Enviromental Contents in Character Education for quality of life ASEAN-Turkey ASLI Conferences on Quality of life. Jakarta: Sosial and Behavioral Science, 222(2016), 244-254.

Puspita, R.H. 2016. Adiwiyata Mewujudkan Sekolah Berbudaya Lingkungan. Warta BP2SDM. Kementrian Lingkungan Hidup dan Kehutanan. http://bp2sdmk.dephut.go.id/emagazine/index.php/umum/59.

Rand, W. 2016. Water and Infrastructure Management. Retrieved from: http://randwater.co.za/pages/Home.aspx.

Saad, N.M., Duasa, J. 2011. An Economic Impact Assessment of A Microcredit Program in Malaysia, The case of Amanah Ikhtiar Malaysia. International Journal of Business and Society, 12(1), 1-14.

SDGs Report. 2015. The Sustainable Development Goals Report. New York: UN. Retrieved from: https://unstats.un.org/sdgs/files/report/2018/TheSustainable DevelopmentGoalsReport.

Shan, Y., Yang, L., Peren, K., Zhang, Y. 2015. Household Water Consumption: Insight from a Survey in Greece and Poland. 13th Computer Control for Water Industry Conference. Scholl of Business \& Economics, 119(1) 1409-1418.

Syme, G.J., Shan. Q., Po, M., Campbell, E. 2014. Predicting and Understanding Home Garden Water Use. Lands Urban Plan. 68, 121-128. 
Soebagyo, L.R., Rachmaningtyas. D, Kusumawardani., Utami, R.B. 2013. Akses terhadap Air Perpipaan di Indonesia Kajian Sosio-Ekonomi. Jurnal Ekonomi dan Bisnis, 23 (1).

Stevenson, E.G.J., Ambelu, A., Caruso, B.A, Refaye, Y., Freman, M.C. 2016. Community Water Improvement, Household Water Insecurity and Women's Psychological Distress: An Intervention and Control Study in Ethiopia. Plops One, 11(4), 1-13.

UNESCO. 2008. Defining an Inclusive Education Agenda: Reflections Around the 48 Session of the International Conference on Education. International Bureau of Education. Geneva Switzerland.

UNESCO. 2015. World Heritage, and Sustainable Development: International Discourses and Local Impacts, Collision or Collaboration, 45-60.

United Nation. 2015. Laporan Pencapaian Milenium Development Goals Indonesia. BAPPENAS.

Vloerbergh, I., Fife Schaw, C., Kelay, T., Chenoweth, J., Morrison, G., Lundehn, C. 2010. Assessing Consumer Preferences for Drinking Water Service: Method for Water utilities. European: Technique.

Wang, X., Feng, H., Xia, Q., Alkire, S. 2016. On the Relationship Between Income Poverty and Multidimensional Poverty in China. OPHI Working Paper 101. The UK: University of Oxford.

Washington, A.C., Hoffman, M. 2008. An Empirical Survey of Residential Water Demand Modelling. Journal of economic Surveys, 22, 824-871.

WCED World Commission on Environment and Development. 1989. Report of The World Commission on Environmental and Development: Our Common Future. United Nations, New York. Retrieved from: http://www.un-documents.

WEEF. 2017. Linking Education and Water in the Sustainable Development Goals United Nations. Transforming our world: the 2030 Agenda for Sustainable Development. Retrieved from: https://sustainabledevelopment.un.org/post2015/transformingourworld.

Zeneli, F. 2016. Drinking Water Demand Determinant is: Evidence from Vlore City. 12th International Strategy Management Conference, 530-536. Antalya Turkey, Procedia Social and Behavioral Sciences. Science Direct.

Zhang, Y., Shan, Y., Perren, K. 2015. Houshould Water Consumption: Insight from a Survey in Greece and Poland. 13th Computer Control Water Industri Conference (CCWI), 119. Loughborough: Prosedia Engineering.10.1016// j.proeng.2015.08.001. 
Correlation of Income Per-Capita, Secondary and Tertiary Education, and Environmental School Quantity to Achieve Clean Water Access in the Sustainable Development Goals 904 